\title{
Literatura e política cultural pelas páginas de Leitura
}

\author{
Cláudia Rio Doce ${ }^{1}$
}

\section{Resumo}

A revista Leitura era um boletim bibliográfico que começou a ser publicado no Rio de Janeiro no início dos anos 1940, tendo como objetivo a popularização da literatura (inserindo-se, assim, na política cultural brasileira do período). Para tanto, promove determinadas ideias como a aproximação do artista e do povo e a democratização da arte, o que resulta em uma série de adaptações feitas pelo próprio periódico ou nele difundidas: traduções, resumos de romances, explicações de obras e autores por eles mesmos ou por seus pares. $\mathrm{O}$ artigo pretende verificar alguns dos conflitos que surgem em suas páginas nos primeiros anos de sua publicação.

Palavras-chave

Literatura, periódicos, política cultural, Estado Novo.

Recebido em 8 de novembro de 2011

Aprovado em 8 de dezembro de 2011

1 Professora Adjunta de Literatura Brasileira e Teoria Literária na Universidade Estadual de Londrina e membro do corpo docente permanente do Programa de Mestrado em Letras na Universidade Estadual do Centro-Oeste (Unicentro). E-mail: claudiariodoce@gmail.com 


\title{
Literature and Cultural Policy through the Pages of Leitura
}

\author{
Cláudia Rio Doce
}

\section{Abstract}

The journal Leitura was a bibliographic bulletin which was first published in Rio de Janeiro in the early 1940s, with the objective of popularizing literature (hence becoming part of the Brazilian cultural policy of the time). To this purpose, it promotes certain ideas such as the rapprochement between the artist and the people, and the democratization of art, thus resulting in a series of adaptations made by the own journal or diffused in it, including translations, novel summaries, explanations of works by the authors themselves or by their peers. This paper intends to verify some of the conflicts that arise in its pages at the first years of its publication.

(4) Keywords

Literature, journals, cultural policy, Estado Novo. 


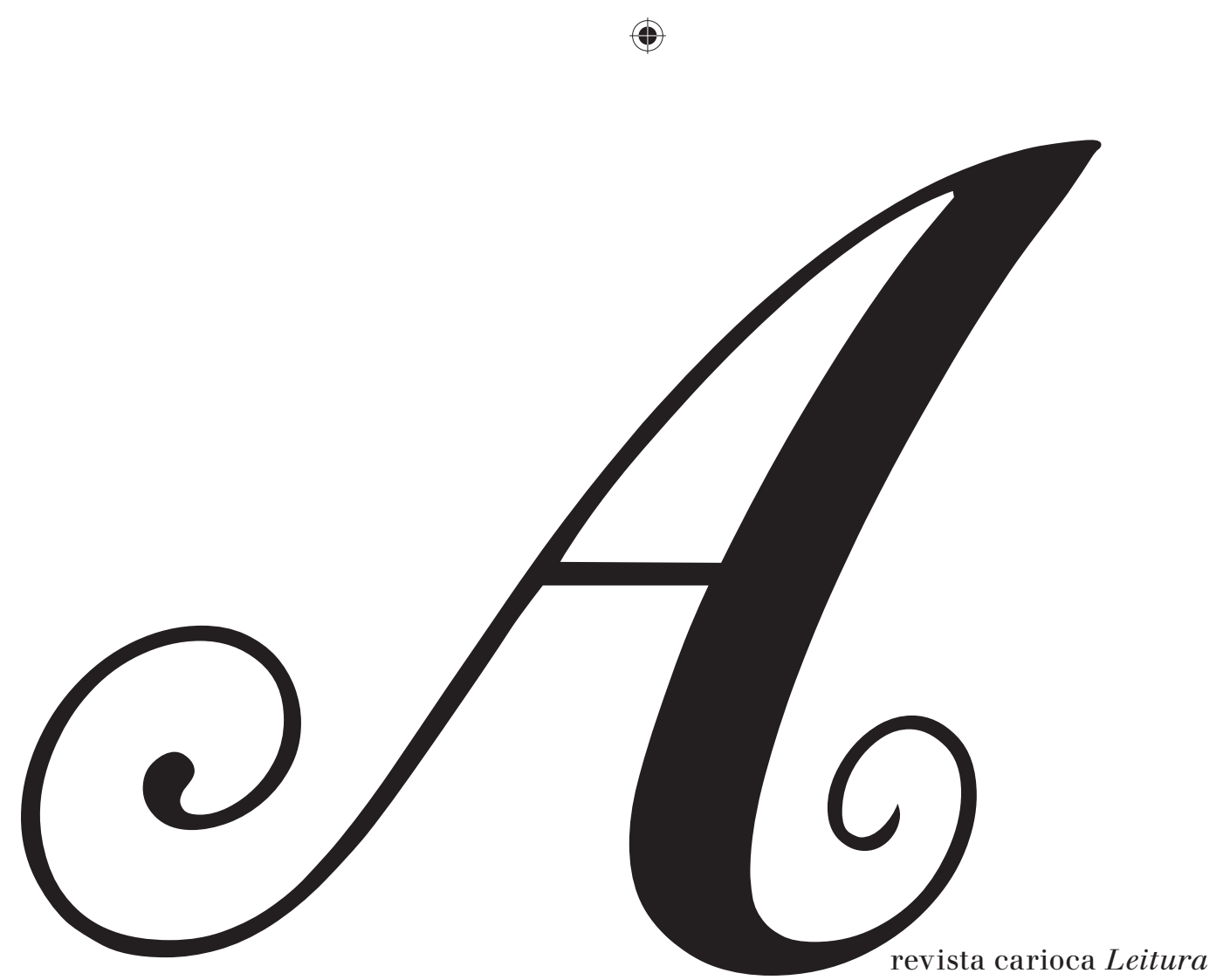

foi concebida como um boletim bibliográfico que, de forma ambivalente, pretendia popularizar a literatura ou, como podemos ler em suas páginas, "vulgarizá-la". Para tanto, assumia, muitas vezes, um tom pedagógico e abordava também outros temas da vida cultural, como cinema e música. Fundada em dezembro de 1942, possuiu vida longa, só se extinguindo em 1965. Este artigo se detém em seus primeiros anos, época em que a conjunção de uma série de fatores favorecia a ideia de democratização da arte não apenas em Leitura, mas em diversas publicações que se ocupavam com a produção cultural.

As lutas ideológicas se exasperam na década de 1930 e, reagindo aos regimes políticos fechados de direita, a intelectualidade de esquerda sobrevaloriza determinadas questões, como a preocupação em tornar a literatura mais acessível, deixando de lado a forma, considerada, muitas vezes, uma questão fútil e da qual poucos podiam fruir. Sobre o assunto, Lafetá sublinha que qualquer nova posição estética deve ser encarada em suas duas faces: enquanto projeto estético (diretamente ligada às modificações operadas na linguagem) e enquanto projeto ideológico (diretamente atada ao pensamento - visão de mundo - de sua época). Depois de cuidadoso estudo da produção e da crítica dos anos 1930, Lafetá conclui que

O raiar dos anos trinta encontra o Modernismo brasileiro em busca de caminhos diferentes. Por um instante parece haver equilíbrio 
entre a concepção de literatura enquanto jogo renovador e revitalizador da linguagem, e a concepção de literatura enquanto reflexo consciente da realidade social. No decorrer do decênio, todavia, a situação se altera: as exigências da luta político-ideológica que se travava no país colorem o projeto estético do Modernismo com novos matizes e o empurram em outras direções. $\mathrm{O}$ experimento de linguagem cede lugar ao documento, a intenção inventiva curva-se à necessidade de registro, a agressividade formal se perde na demagogia verbalista das denúncias. ${ }^{2}$

Dessa maneira, o "engajamento" do artista ficava restrito às possibilidades de comunicar a sua mensagem. Este posicionamento causou, como é conhecido, várias querelas entre os modernistas de 22 e a geração de 30, como fica explícito nas páginas de revistas e jornais do período. Em 1937, por exemplo, Jorge Amado publica o artigo "Poesia e povo" na revista Vamos Ler!. Nele, o autor (que trabalhava, então, na José Olympio) pretende revelar os motivos pelos quais as editoras, nestes anos, relutam em publicar livros de versos, que não vendem:

Para falar franco, eu acho que os modernistas, aqueles heróis que de 1922 até 1928 fizeram uma gritaria tremenda nas letras brasileiras, são os únicos culpados da pouca ou nenhuma venda (vamos dizer nenhuma, que é a verdade) dos livros de poesia no Brasil. São os culpados, afirmo. E passo a provar. (...) Diante do público, editorialmente falando, os modernistas estão muito por baixo. Porque a verdade é que livro de versos nos bons tempos não era "abacaxi". O público lia os versos, comprava os livros e a prova disto é que a Garnier editava muito verso: Castro Alves, Bilac, Raymundo Corrêa, Casimiro de Abreu foram sujeitos que esgotavam edições, vendiam bem seus livros, eram admirados e queridos. Dos modernistas tiram-se edições de 500 exemplares e nem 50 são vendidos. Por que?

É simples. O povo gosta de poesia para ler em voz alta e para declamar nas festas. (...) O interior é assim lírico e belo. Pois bem, eu nunca jamais ouvi recitarem naquelas encantadoras festas de cidade pequena um único poeta modernista. (...) O povo gosta de poesia (...) porque ela é sonora, boa para os ouvidos, boa para os namorados. Hoje ele não tem mais a sua poesia. Os modernistas

2 LAFETÁ, João Luiz. 1930: A crítica e o modernismo. Pref. Antonio Candido. São Paulo: Duas Cidades/Ed. 34, 2000. p. 251-252. 
vieram e com volumes, artigos, conferências, desmoralizaram os poetas passadistas, desmoralizaram a rima e a métrica.

O público ficou envergonhado de acreditar em coisas tão ridículas como métrica e rima. Abandonou seus poetas e ficou esperando pela poesia dos modernistas. Quando esta veio - oh! desilusão - era uma coisa cheia de intenções, de piadas, de subentendidos, uma poesia para ser lida e meditada e muitas vezes não compreendida, nunca uma poesia para o povo ler, recitar, gostar. Ora, o povo já não acreditava nos passadistas que os modernistas tanto tinham ridicularizado. E como estes modernistas eram sujeitos muito acima do público (...), ele não acreditou neles, não aceitou os modernistas, não comprou seus livros, deixou que os livros de poesia se transformassem no pesadelo dos editores. E passou a procurar a poesia nos romances, mesmo nos livros de ensaios, nos homens que não se colocaram acima do povo e, sim, junto do povo. ${ }^{5}$

Em 1945 Oswald de Andrade é preterido por Jorge Amado no posto de "intelectual oficial" do Partido Comunista ${ }^{4}$. À diferença do escritor baiano, que defende uma literatura acessível ao povo, o antropófago reivindicava condições para que o povo tivesse acesso ao hermetismo da alta cultura, formulando a frase tão conhecida: "a massa há de chegar ao biscoito fino que eu fabrico".

Percebemos, então, nas diferenças entre estes dois autores que seguiam, em princípio, o mesmo direcionamento político, a prefiguração do conflito entre obra de arte e mercadoria. Porque justamente a referência da qual se utiliza Jorge Amado para julgar a poesia é o seu sucesso - insucesso - de vendas. Seguindo sua argumentação, poderíamos dizer que, se o povo não compra, logo, a poesia não serve para ele. Não serve porque carece de alguma coisa da qual ele precisa. Lirismo? Beleza? Compreensão sem raciocínio? É precisamente neste hiato que muitas vezes se confunde o estésico com o anestésico. Sendo assim, mais do que o conflito entre arte e mercadoria, voltamos à dicotomia estetização da política-politização da arte. Na leitura que Susan Buck-Morss faz do "ensaio da obra de arte", ela redimensiona esta dicotomia proposta por Benjamin:

3 AMADO, Jorge. Poesia e povo. Vamos ler!, maio 1937. p. 3.

4 O fato se deu quando Oswald de Andrade ia saudar Pablo Neruda num comício no estádio do Pacaembu e, na última hora, o quadro dirigente do Partido Comunista resolve conceder o privilégio a Jorge Amado. Sobre esta questão, bem como todo o envolvimento de Oswald com o PC, ver a biografia do autor escrita por Maria Augusta Fonseca, principalmente o capítulo 17: FONSECA, Maria Augusta. Oswald de Andrade - biografia. São Paulo: Arte, 1990 
Benjamin está dizendo que a alienação sensorial se encontra na origem da estetização da política, a qual o fascismo não cria, mas apenas "manipula". Parte-se do princípio de que a alienação e a política estetizada, enquanto condições sensuais da modernidade, sobrevivem para além do fascismo (...). A resposta comunista a esta crise é a "politização da arte", implicando em que? (...) Desfazer a alienação do aparato sensorial do corpo, restaurar o poder instintual dos sentidos (...), e isto não através do rechaço às novas tecnologias, mas pela passagem por elas. ${ }^{5}$

As divergências entre os escritores das duas gerações não impediu, no entanto, que o polêmico Oswald tenha considerado, apesar de tudo, que a fertilidade da produção destes anos e sua preocupação com os problemas sociais tivessem papel preponderante na queda da ditadura ${ }^{6}$ Por outro lado, a suposta "aproximação" entre o artista e o povo, que é o argumento central de Jorge Amado e sua reivindicação para a literatura, não deixa de ser uma concepção política populista e demagógica. Além de tendência dos militantes de esquerda, torna-se preceito da política cultural do Estado autoritário, pois o Departamento de Imprensa e Propaganda (DIP) assim estabelece seus objetivos (nas palavras de Almir de Andrade): "através das instituições políticas, interpretar, defender, amparar, estimular e encarnar, nas formas e sistemas do governo, os quadros de costumes nos quais desponta a alma do povo"7.

Estamos em uma época em que o Brasil se desenvolve muito industrialmente, e como afirma Nelson Werneck Sodré:

Assim como um dos grandes problemas do desenvolvimento material, no país, está na incorporação progressiva à economia de mercado das vastas áreas em que predomina ainda a economia natural, um dos grandes problemas do desenvolvimento cultural, no Brasil, está

5 BUCK-MORSS, Susan. Estética e anestética: o "ensaio sobre a obra de arte" de Walter Benjamin reconsiderado. Travessia, n. 33, ago-dez 1996, p. 12. "De outro modo", anota ainda a autora, "as duas condições, crise e resposta, acabariam por ser a mesma coisa. Uma vez a arte inserida na política (política comunista não menos que política fascista), o que poderia aquela fazer senão pôr-se ao serviço desta, transmitindo assim à política os seus próprios poderes artísticos, i. e., ‘estetizar a política'?” (trad. Rafael Lopes Azize)

6 Ver a retrospectiva que o autor faz do modernismo e da produção literária da década de 1930 em "Informe sobre o modernismo", disponível no volume Estética e política: ANDRADE, Oswald de. Estética e politica. (Obras completas). Pref. Maria Eugenia Boaventura. São Paulo: Globo, 1991.

7 ANTELO, Raul. Literatura em revista. São Paulo: Ática, 1984. p. 59. 
na incorporação progressiva ao público das camadas sociais que a vida mantém distanciadas e indiferentes às suas manifestações. ${ }^{8}$

O autor adverte, ainda, que é com o desenvolvimento das relações capitalistas e a busca pelo trabalho qualificado que se impõe a necessidade de fornecer conhecimentos a camadas mais numerosas da população. Sérgio Miceli $^{9}$, por sua vez, constata que o Estado - que abria cargos especializados onde um considerável número de intelectuais prestavam diversos tipos de colaboração à política cultural do governo Vargas - serviu de intermediário nesse processo. Além de toda esta confluência de interesses que observamos no Estado autoritário e em militantes de esquerda (atingir públicos mais amplos), levemos em conta também que a questão fazia parte, ainda, da agenda internacional, através da política de boa vizinhança, vivida intensamente pelo Brasil nestes anos. Colocada em prática por Roosevelt, tinha como discurso integrar os países americanos, fazer com que se conhecessem e se ajudassem mutuamente. Na prática, devia difundir o american way of life entre os países latino-americanos mostrando um mundo atraente de consumo e progresso pelo rádio, cinema e revistas - e conquistar esta parte do continente como "mercado".

Muitos dos aspectos dessa política cultural do período aparecem nas páginas de Leitura, inclusive seus conflitos. Estudando determinadas colunas e artigos da revista, procuramos verificar as relações que se estabelecem, os pontos de contato ou os distanciamentos existentes nas posturas estéticas e opiniões de time, tão diversificado como aquele formado por seus colaboradores. Podemos iniciar essa tarefa buscando o próprio conceito de literatura que se tenta difundir. Alguns indícios nos são dados pela explicação presente na coluna "Auto-retrato" por ocasião de seu lançamento, dizendo que:

Esta coluna de "LEITURA" é dedicada aos grandes nomes que honram a literatura brasileira. Não tem outra finalidade senão a de prestar algumas informações sobre a vida daqueles que, pelo talento e pela honestidade literária, deixaram de pertencer a si mesmos, para se tornarem figuras do povo.

Aparecerá mensalmente feita pelo próprio escritor convidado em cada número. ${ }^{10}$

8 SODRÉ, Nelson Werneck. Síntese de história da cultura brasileira. Rio de Janeiro/São Paulo: Bertrand Brasil, 1994. p. 7 o.

9 MICELI, Sérgio. Intelectuais e classe dirigente no Brasil (1920-1945). São Paulo/Rio de Janeiro: Difel, 1979.

10 Leitura, 1942. p. 11.

revista ieb $n_{54} 2012$ set./mar. p. 67-86 
Notemos que o fragmento fala de uma "honestidade" literária, termo que em outras ocasiões é substituído por "sinceridade" ou "verdade" e que pretende ser o elo entre o escritor e o povo, entre a literatura e o grande público, que se buscava então. Segundo o que podemos encontrar na revista, Seleções é um sucesso editorial pela "honestidade de seus artigos"; muitos romances devem ser lidos porque "não mentem", porque suas personagens "vivem de verdade", porque seus autores têm "honestidade intelectual". No entanto, o que seria esta honestidade ou verdade? Elas nos aparecem para tratar de concepções muito diversas e podemos tomar como exemplo a própria coluna "Auto-retrato".

Escritores falando de si mesmos e procurando aproximar-se do público. Duas posturas distintas são observadas e, entre elas, toda uma gradação. A primeira é melhor exemplificada no caso de Graciliano Ramos, que se despoja de toda e qualquer caracterização que possa particularizá-lo para descrever-se como mais um: sua infância pobre no Nordeste, a seca, a dificuldade do aprendizado que fez dele um aluno medíocre. Depois fala dos cargos públicos que ocupou, como se nunca tivesse tido competência para ocupá-los, e dos livros que escreveu, como se fossem histórias banais que, por motivo inexplicável, tivessem atingido o sucesso. Finaliza falando de seu momento atual:

Mudei-me para o Rio, ou antes, mudaram-me para o Rio, onde existo, agora. Aqui fiz meu último livro, história mesquinha - um casal vagabundo, uma cachorra e dois meninos. Certamente não ficarei na cidade grande. Preciso sair. Apesar de não gostar de viagens, sempre vivi de arribada, como um cigano. Projetos não tenho. Estou no fim da vida, se é que a isso se pode dar o nome de vida. Instrução quase nenhuma. José Lins do Rego tem razão quando afirma que a minha cultura, moderada, foi obtida em almanaques. ${ }^{11}$

As circunstâncias da vida o arrastam, e ele apenas constata os acontecimentos como se fossem inevitáveis, como se não dependessem de sua vontade. Sua identificação com a massa e sua modéstia são tais que o redator acrescenta uma nota para esclarecer o público de que "o último livro a que Graciliano Ramos se refere, chamando-o de 'história mesquinha' (...) é 'VIDAS SECAS' - um grande romance consagrado pela crítica brasileira”. Único artigo da coluna que sofre alguma intervenção da revista.

11 RAMOS, Graciliano. Auto-retrato. Leitura, dez. 1942. p. 12.

revista ieb $n_{54} 2012$ set./mar. p. 67-86 
Na extremidade oposta temos Jorge de Lima, que se limita, em seu autorretrato, aos fatos de sua formação e vida intelectual. Fala de suas concepções artísticas e de sua produção literária. E critica:

Muitos me chamam de diletante: acho que o artista tem a sua realidade própria, e não está sujeito a nenhuma exigência superior. Não faço o que poderia agradar aos outros, mas o que nasce em mim e luta para se libertar de minha sensibilidade, sem ligar a qualquer espécie de chatos.

Aliás, parece que o que há, no Brasil, com os escritores, é um inexplicável medo de ser "eles mesmos", sem premeditações nem compromissos. Muitos são os espécimes de homens de letras que traem a si mesmo, não tendo coragem de enfrentar a crítica, preferindo realizar coisas impessoais e informes.

(...)

Há quem me acuse de não compreender a missão social do escritor, nos dias de hoje, em que as forças da opressão pretendem sufocar a liberdade e os direitos humanos. Há nisto outro engano. Meus poemas, (...) toda a minha obra literária, é social, porque nela eu falo do homem, de sua presença no mundo, de suas lutas e sofrimentos, de suas inquietações e de seus desejos. Aliás, ninguém pode fazer um romance dizendo de início: "Vou já, já escrever um romance social". Puro engano. O romance é que emerge do social, revolucionário, católico, etc., impressentidamente, como se revelasse ao escritor sua alma grafada em letra de fôrma. ${ }^{12}$

Jorge de Lima, portanto, aponta para o fato de que se, de uma forma geral, a valorização do escritor e de sua obra passava, naquele momento, pela ideia do intelectual engajado, cuja defesa de determinados valores ou atitudes lhe emprestava autoridade e integridade moral, ou seja, "honestidade", alcançando assim eficácia junto à opinião pública, para ele, ao contrário, o escritor deveria estar comprometido, antes de mais nada, com a própria arte. Neste caso, a "honestidade literária" estaria relacionada a uma coerência com suas próprias convicções artísticas, e não com qualquer tipo de comprometimento social ou político. Jorge de Lima ressalta, ainda, que não escreve para o mercado e defende que a literatura deveria, ao contrário, manter-se imune a este. Desta maneira, o potencial crítico e de resistência da obra emergiria do próprio ato criador, e não seria artificialmente imposto por condições externas.

12 LIMA, Jorge de. Auto-retrato. Leitura, mar. 1943. p. 15.

75

revista ieb $n_{54} 2012$ set./mar. p. 67-86 
Entre esses polos - uma vida cuja realidade avassaladora torna a arte insignificante e uma vida que só adquire sentido através da arte - há toda uma gama de textos nos quais uma reflexão sobre a própria arte e valores artísticos se mescla com aspectos da vida pessoal de seus autores. Desta maneira, busca-se explicitar as possíveis conexões entre discurso e vida fora do texto. Seus autores, ao mencionarem os lugares e momentos de suas vidas em que determinados eventos ocorreram, procuram dar mais autenticidade ao relato, atestando a sua "sinceridade". No entanto, vários deles demonstram claramente que o texto não passa de uma representação, uma construção narrativa. Esse aspecto não entra em choque com a ideia de "sinceridade", como poderíamos supor. Antes, pelo contrário, a reforça, seja porque apontam para a representação a fim de negá-la ou simplesmente pela confissão de estarem recorrendo a ela. Assim, Oswald de Andrade, ao alegar que seu autorretrato sairia favorecido, apenas fornece "elementos para um retrato" que não acontece). Galeão Coutinho menciona que poderia "dizer coisas lindas" ${ }^{14}$ de si próprio, mas não o faz. Eloi Pontes diz que o "comum é dissimular", mas, como não quer mentir nem tem coragem de revelar "tudo", prefere "concluir singelamente" ${ }^{15}$ seu texto. Jorge de Lima aponta para a impossibilidade de uma "fidelidade de espelho", concluindo que mostrou apenas "fragmentos de espelho" aos quais procurou dar "um tom de sinceridade" ${ }^{\prime 6}$. Ou seja, explicita que a sinceridade é aparente, também faz parte da autorrepresentação. E Sérgio Milliet avisa que sua tendência para a caricatura vai deformar o retrato ${ }^{17}$.

Marques Rebelo e Dias da Costa inventam personagens de si mesmos, reforçando a ideia de encenação. Falam em primeira pessoa, mas criam diálogos e situações imaginárias. Drummond leva a brincadeira mais longe. Começando seu texto com a frase "Diz o espelho", escreve seu autorretrato em terceira pessoa, o que lhe reserva uma liberdade bem maior para falar de si mesmo, de sua obra e de seus críticos. Num tom especulativo, e com muita ironia, trata o "sr. Drummond"18 e os críticos literários da mesma maneira, utilizando-se de opiniões alheias para avaliar sua própria obra e pessoa. Aliás, este expediente, de recorrer à opinião dos críticos para avaliar a própria obra ou dos amigos para avaliar a própria pessoa, é utilizado por outros escritores também, talvez para diminuir o desconforto de ser, ao

13 ANDRADE, Oswald de. Auto-retrato. Leitura, maio 1943. p. 13.

COUTINHO, Galeão. Auto-retrato. Leitura, jul. 1943. p. 31.

15 PONTES, Eloi. Auto-retrato. Leitura, fev. 1943. p. 15.

6 LIMA, Jorge de. Auto-retrato. Leitura, mar. 1943. p. 15.

MILLIET, Sergio. Auto-retrato. Leitura, nov. 1943. p. 21.

ANDRADE, Carlos Drummond de. Auto-retrato. Leitura, jun. 1943. p. 15.

76

revista ieb $n_{54} 2012$ set./mar. p. 67-86 
mesmo tempo, sujeito e objeto de observação e análise, ou um artifício para que a narrativa ganhe mais credibilidade.

Se a "sinceridade" ou aparència de sinceridade ajuda a aproximar o escritor de seus leitores, pelo que poderia haver aí de pessoal e, até mesmo, confessional, outra forma de aproximação é quando se mostra uma possível afinidade, como faz Dias da Costa ${ }^{19}$, que se define como antifascista e torcedor do Flamengo. E enquanto alguns se identificam com o "povo", outros se mostram condescendentes para com ele. Assim, José Lins do Rego, que sintetiza sua vida na frase "de menino rico a funcionário bem pago", afirma: "sei que amo a humanidade porque odeio as tiranias com todo o peso de um corpo e toda a pureza de minha alma" ${ }^{20}$. Eloi Pontes nunca desejou "ser mais do que os proletários" os pequenos e sofre com eles" 22 .

Já Oswald de Andrade ${ }^{25}$, procurando mostrar que seu comprometimento vai muito além das palavras, que é uma pessoa de "ação", conta que já foi preso e esteve foragido diversas vezes, e que tomou parte em conflitos públicos em 1931, quando dirigia o jornal $O$ homem do povo. Apontando, assim, de maneira surpreendente, que é contrário ao regime vigente.

Percebemos que a aproximação entre escritores e povo é uma questão que se desdobra através de outras colunas de Leitura e que a revista pretende mostrar que tal aproximação não deve ocorrer apenas num possível imaginário comum, gosto compartilhado, problemas semelhantes vividos, mas principalmente no estabelecimento de um mercado consumidor de livros. Procurando, talvez, informar-se sobre os hábitos e as preferências de um possível público ainda em formação, Leitura cria "Um romancista no meio do povo", título que comporta a dupla referência do que a coluna nos propõe: a cada número, um escritor designado pela revista sai às ruas para se informar sobre a popularidade de outro escritor. E nesta função, os repórteres fazem os mais diversos tipos de observações, sobre os autores que são objetos de suas investigações e suas obras, sobre a popularidade ou não da literatura, sobre a existência ou inexistência de um mercado para os livros, sobre a "cultura do povo", de uma forma geral e, até mesmo, sobre a tarefa dada pela revista. As opiniões são as mais variadas e algumas vezes contraditórias.

Dalcídio Jurandir inaugura a coluna fazendo reportagem sobre José Lins do Rego. Apesar de afirmar que, ao que lhe parece, José Lins

19 COSTA, Dias da. Auto-retrato. Leitura, out. 1943. p. 18.

20 REGO, José Lins do. Auto-retrato. Leitura, jan. 1943. p. 19.

21 PONTES, Eloi. op. cit. p. 15.

22 REBELO, Marques. Auto-retrato. Leitura, ago. 1943. p. 20.

23 ANDRADE, Oswald de. op. cit. p. 13.

revista ieb $n 542012$ set./mar. p. 67-86 
seja o escritor mais popular, com seus romances sobre o ciclo da cana-de-açúcar, pondera que, para que houvesse, realmente, um mercado de público leitor, muito teria que ser feito em matéria de educação. Além de uma enorme parcela da população ainda ser analfabeta, os livros podiam ser considerados artigos de luxo. Seus preços estavam muito além do poder aquisitivo da maioria das pessoas ${ }^{24}$.

Joel Silveira, ao fazer a reportagem sobre a popularidade de Erico Verissimo, opina que ele leva vantagem sobre qualquer outro escritor em termos de público e se questiona se isso pode ser tomado como elogio ou como restrição. $\mathrm{O}$ repórter considera a preferência do público por histórias fáceis e bem-acabadas, o fato de suas escolhas não privilegiarem tese ou estilo e conclui que os últimos livros do escritor gaúcho fizeram concessões aos leitores inimigos das situações difíceis e dos problemas abstratos. "Daí esta alegria: quase todo mundo conhece ou já leu Erico Verissimo”"25.

Valdemar Cavalcanti ${ }^{26}$, por sua vez, ao ser designado para verificar o prestígio de Jorge de Lima junto ao público, se pergunta sobre esta possibilidade existir, uma vez que sua arte não é acessível ao gosto comum, à sensibilidade do povo. Galeão Coutinho ${ }^{27}$ faz observação semelhante sobre a obra de Graciliano, dizendo que o público acostumado com romances que acabam em casamento e filmes que terminam em beijos certamente não é o público para um romance como Angústia.

Josué Montello, ao contrário, acredita que Jorge Amado possui um público numeroso e invejável, constituído pelas massas populares, e não pelas elites. "E nisto repousa a sua glória, que é construída no propósito de revolver a consciência humana e iluminá-la com os líricos clarões de uma fé permanente na melhoria social dos homens sobre a terra" ${ }^{28}$. E José Lins do Rego entrevista um torcedor do Botafogo, cearense, que lhe garante que seu pai sabe "quase todo decorado" ${ }^{29}$ o romance A bagaceira, de José Américo.

Sobre os hábitos de leitura do "povo", constatam quase sempre o mesmo. Poucas são as pessoas que leem. A maioria alega não ter tempo

24 JURANDIR, Dalcídio. Um romancista no meio do povo. Reportagem de Dalcídio Jurandir sobre José Lins do Rego. Leitura, dez. 1942. p. 17.

25 SILVEIRA, Joel. Um romancista no meio do povo. Reportagem de Joel Silveira sobre Erico Verissimo. Leitura, jan. 1943. p. 9-26.

26 CAVALCANTI, Valdemar. Um romancista no meio do povo. Reportagem de Valdemar Cavalcanti sobre Jorge de Lima. Leitura, ago. 1943. p. 31.

27 COUTINHO, Galeão. Um romancista no meio do povo. Reportagem de Galeão Coutinho sobre Graciliano Ramos. Leitura, mar. 1943. p. 9-18.

28 MONTELLO, Josué. Um romancista no meio do povo. Reportagem de Josué Montello sobre Jorge Amado. Leitura, jun. 1943. p. 11-12.

29 REGO, José Lins do. Um romancista no meio do povo. Reportagem de José Lins sobre José Américo. Leitura, jul. 1943. p. 23.

revista ieb $\quad n_{54} 2012$ set./mar. p. 67-86 
para ler ou dinheiro para comprar livros. Aqueles que leem alguma coisa o fazem dentro dos bondes ou trens, e geralmente livros que conseguem emprestados, não escolhendo autor ou estilo. Também não se preocupam em saber o nome do autor das obras. Muitos ressaltam sua predileção por ouvir o "teatro pelo rádio", assistir aos jogos de futebol ou ir ao cinema, em seu tempo livre. E se José Lins e Josué Montello procuram mostrar que as obras de Jorge Amado e José Américo são conhecidas porque o público se identifica com o drama vivido pelas personagens, gente do povo como eles, alguns leitores demonstram posições opostas. Dias da Costa ${ }^{30}$, quando explica a uma das moças entrevistadas que Os corumbas fala sobre a vida de uma família pobre, em Sergipe, escuta a resposta indignada: “- Em Sergipe?!! Não gosto não. Gosto de livro que se passe na França, que tenha condes, castelos, gente alinhada" ${ }^{31}$.

É curioso notar que, ao mesmo tempo em que os autores da coluna constatam que muitas pessoas não leem porque não podem comprar livros, argumentam que pegar emprestado não é um bom hábito, que o melhor é adquirirem seus próprios volumes, o que demonstra uma grande contradição e alguma falta de sensibilidade, pois invertem a lógica de que primeiro se deve adquirir o hábito e o gosto pela leitura, para depois se tornar consumidor de livros. Parece que defendem mais a existência de um mercado consumidor do que a constituição de um público leitor. Galeão Coutinho é alertado, por um de seus entrevistados, desse disparate. $O$ rapaz lhe diz que compra muitos livros. Os que gosta passa adiante, empresta para que outros leiam também. "Observei-lhe que era um mau hábito, esse de emprestar livros. Obtemperou-me que não. Tomando livros de empréstimo, o sujeito habitua-se à leitura e acaba freguês de livrarias. De fato, assim é”32.

Esse desejo e necessidade de se constituir um público leitor no Brasil é outro tema recorrente na revista. Vários artigos abordam o assunto por diferentes vias: empreendimentos editoriais, promoção de bibliotecas públicas e exploração da ideia de que o aparato visual torna mais prazerosa a leitura, associando livros e filmes. A questão se amplia através da coluna "Leitura condensa um romance", que aparece no número 4 da revista, de março de 1943. Convém ressaltar que, de início, esta era constituída de um resumo detalhado de todos os acontecimentos do livro, mas de leitura

3o COSTA, Dias da. Um romancista no meio do povo. Reportagem de Dias da Costa sobre Amando Fontes. Leitura, abr. 1943. p. 9 .

31 Poucos são os artigos da revista que defendem a literatura como entretenimento, argumentando justamente que serve como uma distração dos problemas da vida, que já são muitos.

32 COUTINHO, Galeão. Um romancista no meio do povo. Reportagem de Galeão Coutinho sobre Graciliano Ramos. Leitura, mar. p. 9-18.

revista ieb $\quad n_{54} 2012$ set./mar. p. 67-86 
um pouco confusa, difícil. Os primeiros artigos não eram assinados. $\mathrm{Na}$ terceira condensação da série, de Éramos seis, o resumo já adquire certa forma. Está mais palatável, um texto de leitura mais agradável. A assinatura do responsável, Raul Lima, vem no final. A partir da edição de junho de 1943, com a apresentação do resumo de Memórias de um sargento de milícias, o nome do responsável pelo texto vem no cabeçalho, logo abaixo do título: "Condensação de Raul Lima".

Não podemos deixar de mencionar que, na edição imediatamente anterior ao aparecimento dessa coluna, há um artigo na revista falando sobre o sucesso alcançado por Seleções de Reader's Digest junto ao público:

É natural que os editores do país vejam com muito bons olhos a extraordinária aceitação do Rider's Digest. (...) Essas "Seleções", intelectual e economicamente acessíveis, foram descobrir, despertar e criar leitores que já não mais se conformam com as leituras digeridas do próprio Rider's Digest. (...)

Um romance, cuja condensação aparece nas "Seleções", será um livro procuradíssimo (...).

É bem provável que milhares de leitores não se sentiram inteiramente satisfeitos só com a condensação da última novela de Steinbeck, "A Lua caiu": querem a novela inteira. O raciocínio é simples, baseia-se no interesse espontâneo que uma leitura des-perta para com novas leituras, e não precisa ser mais explicado.

O certo é que, com um ano de circulação, sempre crescente, se pode afirmar sem receio que as "Seleções" criaram, efetivamente, muitos leitores e trouxeram à luz da estatística a certeza de que existe um imenso público no Brasil, capaz de apoiar revistas bem dirigidas, de igual interesse e com uma tiragem superior a 300 mil exemplares. A questão é aproximar-se realmente do povo, é penetrar-lhe o gosto com a humildade do preço e a excelência, a simplicidade e a honestidade dos artigos..$^{33}$

Seleções apareceu no Brasil no início de 1942. Como o próprio nome indica, era composta por uma seleção de textos de fácil assimilação. Editada em português nos Estados Unidos, esperava divulgar entre nós o american way of life, e a seção que mais se popularizou foi justamente a de livros. Os textos eram simplificados e resumidos para facilitar a leitura, mas conservavam "o poder de atração da narrativa", como dizia seu texto de abertura ${ }^{34}$.

33 Seleções e os editores. Leitura, fev. 1943. p. 7 .

34. Sobre o lançamento de Seleções, bem como das demais atividades do Office for Coordination of Commercial and Relations between the Americas de Rockefeller no Brasil, ver 
Portanto, Leitura aproveita a ideia e o sucesso desta seção de Seleções para seus próprios ideais: constituir um público leitor no Brasil e divulgar a literatura brasileira. E podemos claramente perceber que dominar a técnica de manter, no resumo, "o poder de atração da narrativa" foi um processo que se deu gradativamente em Leitura.

O que podemos observar na revista é a formação de determinado perfil que se desdobra através de suas colunas e artigos, o que não quer dizer que não haja espaço para opiniões contrárias. Estas são em número bem menor, é verdade, mas contundentes. Não chegam a configurar uma polêmica, apenas algumas vozes dissonantes do conjunto. A ideia principal da "boa literatura", tal como entendida pela revista, é aquela engajada, preocupada com as grandes causas sociais. O "bom escritor" é aquele que, por se preocupar com as grandes causas sociais, está próximo do povo. E como justificativa desses valores, o que se faz sentir a cada página, antes de mais nada, são os horrores da Segunda Guerra. Leitura divulga os inúmeros livros sobre a guerra, escritos por pessoas que dela participaram e deram seus depoimentos, ficcionalizando-os ou não. Difunde e acompanha, nas colunas de notícias, a destruição dos bens culturais promovida pelos nazistas nos países que ocupam. São inúmeras as fogueiras de livros, bibliotecas e museus destruídos, universidades fechadas, artistas mortos, torturados, enviados para os campos de concentração. Diante do pavor e aniquilação das cidades bombardeadas, todos se irmanam em sua condição mais instintiva e intuitiva: são sobreviventes buscando meios elementares para continuarem vivos. E manter viva a sua cultura, sua identidade. A revista nos informa, portanto, que todos lutam juntos pelas mesmas coisas, não há mais distinção entre artista e povo.

Diante desta aterradora realidade surgem algumas inquietações nos colaboradores da revista. Em "Uma folha na tempestade", Luis Martins se pergunta sobre a possibilidade de se fazer literatura. Ele, então, conclama:

Poesia, façam poesia! Mas não nos chateiem com pequenas aventuras sentimentais de personagens que nem existem, quando um simples repórter pode descrever dramas muito mais extraordinários do que todos os romancistas do mundo reunidos poderiam conceber.

Ora, se Lin Yutang me reconciliou com o romance, é porque há em seu livro uma grande porção de reportagem..$^{35}$

o primeiro capítulo de O imperialismo sedutor. A americanização do Brasil na época da Segunda guerra, de Antonio Pedro Tota (São Paulo: Companhia das Letras, 200o).

35 MARTINS, Luis. Uma folha na tempestade. Leitura, jan. 1943. p. 11. 
Explica-se, assim, a importância da arte comprometida com a verdade e a denúncia ${ }^{36}$. Como mencionamos anteriormente, não raras vezes, tanto nos artigos como nas colunas, há a valorização de romances que têm personagens que "vivem de verdade", que não são "bonecos" nem "seres inventados", bem como do escritor que compõe seu texto intuitivamente, em contraposição ao saber técnico, ao autor que se utiliza de "truques" de construção, de "métodos e processos esquemáticos absorvidos às pressas". Essa postura da revista, no entanto, acaba tratando com indistinção todas as obras de caráter testemunhal.

Se a então recente adesão do Brasil aos Aliados possibilita algumas das questões abordadas, traz, simultaneamente, interessantes nuances para elas. O governo Vargas mantinha relações diplomáticas e comerciais tanto com os Estados Unidos quanto com a Alemanha desde a década de 1930, fazendo um jogo duplo para tirar maior proveito das negociações, embora tenha buscado aproximar-se do Eixo até 1939. Em junho de 1940, Getúlio Vargas faz um pronunciamento cheio de mensagens dúbias, criticando a democracia, o que pareceu para muitos um discurso germanófilo. Apesar do mal-estar provocado, Vargas contorna a tensa situação gerada com os Estados Unidos manifestando simpatia pela política de solidariedade panamericana proposta por Roosevelt. $\mathrm{O}$ governo brasileiro adia ao máximo uma tomada de postura definitiva, só rompendo as relações diplomáticas com a Alemanha, a Itália e o Japão no início de 1942, e só reconhecendo o "estado de guerra" em agosto, depois que navios mercantes brasileiros foram bombardeados pela marinha alemã. Muitos anos mais tarde, correu o boato (que não foi comprovado) de que os próprios Estados Unidos teriam atacado os navios brasileiros para forçar o Brasil a entrar na guerra.

Portanto, quando Leitura apareceu, em dezembro de 1942, o Brasil já estava em guerra e vivia intensamente a política de boa vizinhança, intercambiando produtos culturais com os demais países da América. Existia, no entanto, uma contradição daquele momento no Estado Novo. O Brasil entrou em guerra contra o Eixo, mas, ao mesmo tempo, possuía uma Constituição fascista, que tinha sido baseada na Carta del Lavoro italiana e na carta fascista polonesa de $1935^{37}$.

Assim, quando na revista apareciam artigos com críticas aos regimes autoritários, quando se reforçava a necessidade de se hostilizar toda forma de tirania, perseguição, demonstração de força, preconceito e intransi-

$3^{6}$ E a equiparação, na coluna "Auto-retrato", de escritores reconhecidos com outros que se destacaram por sua atuação jornalística e não pela produção literária, como "grandes nomes de nossa literatura".

37 LEVINE, Robert M. Pai dos pobres? O Brasil e a era Vargas. Trad. Anna Olga de Barros Barreto. São Paulo: Companhia das Letras, 2001. p. 82-83. 
gência, havia uma dupla referência. A mais óbvia, e que geralmente era o pretexto para o surgimento do assunto, a guerra contra o nazismo, e outra, nem sempre muito velada, o regime ditatorial do Estado Novo.

Afirmava-se, igualmente, a necessidade de uma resistência ao autoritarismo, de luta pela liberdade, associando, inclusive, o desenvolvimento da educação e da vida intelectual à liberdade de pesquisa, opinião e pensamento, o que não acontecia na Europa tomada nem no Brasil, onde a produção cultural era submetida à censura. Chega-se mesmo a afirmar que "todo governo que domina a massa e a inteligência, e não mais lhe representa a vontade, é um governo pré-fascista" \$3. Talvez para minimizar o possível impacto de tais afirmativas, há também elogios aos empreendimentos do governo, exaltando-se, inclusive, a adesão do Brasil à guerra, com as palavras: "outro não deveria ser o gesto de quem interpreta as emoções

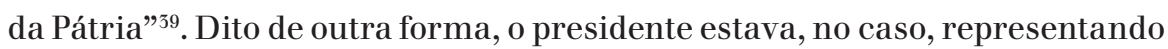
a vontade do povo, não se caracterizando, portanto, como pré-fascista.

O intercâmbio promovido pela política de boa vizinhança também era fartamente divulgado pela revista. Apesar de ser mais notório o intercâmbio de obras e artistas entre o Brasil e os Estados Unidos, houve também uma aproximação muito grande entre os países da América Latina. Algumas notícias sempre estão presentes, mas em julho de 1943 apareceu a coluna "Caminhos da América", que não só registrava o intercâmbio como também algumas notícias dos acontecimentos culturais. Conta-se, por exemplo, que a revista argentina Hoy traduziu e publicou em suas páginas alguns autorretratos de Leitura. Da mesma forma, Leitura publicava alguns artigos estrangeiros, traduzidos para o português.

Diferindo do tom habitual, noticia-se, com algum alarde, a passagem de Maria Rosa Oliver pelo Rio de Janeiro. Maria Rosa integrava o grupo da revista Sur, dirigida por Victoria $\mathrm{Ocampo}^{40}$, e esteve no Rio causando rebuliço entre os intelectuais, antes de embarcar para os Estados Unidos, onde coordenaria trabalhos de relação cultural com a Argentina. Melo Lima, autor do artigo, transcreve alguma coisa do diálogo com ela, como a frase que muito o surpreendeu, pela força com que foi dita, "Não admito mais ninguém que

38 Leitura, 1943. p. zo.

39 DUARTE, Dioclesio. Porque estamos em guerra. Leitura, fev. 1943. p. 9.

$4^{\circ}$ Vale lembrar que a revista argentina Sur, que nunca se interessara por questões brasileiras, dedica inteiramente seu número de setembro de 1942 à literatura brasileira felicitando ainda a postura brasileira pró-Aliados diante da guerra contra os nazistas. Esta atitude marca o posicionamento dos intelectuais argentinos, insatisfeitos com a postura de seu governo de manter a neutralidade perante a guerra. Surtornouse um símbolo da resistência ao peronismo. Sua diretora, Victoria Ocampo, chegou a ser presa sem culpa formada. 
não seja político"'11. Ele acaba confessando que muito do que conversaram não pode ser dito no texto, "vocês compreendem", fazendo uma clara alusão de que o "político" a que ela se refere é muito mais imediato do que o "antifascismo" que se transformara em moeda corrente nas páginas de Leitura.

Outros artigos interessantes são os intitulados "A contribuição da inteligência para a Unidade Continental"42, que deveriam constituir uma nova coluna, o que não chegou a acontecer. O primeiro é uma entrevista com o embaixador do Chile no Brasil, e o segundo com o embaixador do Uruguai. Traziam ideias dos embaixadores do que poderia ser feito para se intensificar o intercâmbio cultural do Brasil com seus países. A facilitação de trocas de bens culturais, o intercâmbio de jornalistas, um maior interesse pelo que acontece nos países vizinhos, dando maior destaque nos jornais para isso - muitas ideias são apontadas. E, como vimos, algumas acatadas pela própria Leitura, que inaugura coluna própria para tal fim. o entanto, Gonzalez Videla, o embaixador do Chile, menciona outro meio de aproximação que perpassa os interesses da revista:

Finalmente, existe um sistema de aproximação cultural e espiritual que não devemos esquecer e cuja importância cresce de dia para dia. Refiro-me ao cinema. A história de um país, a vida de um homem de projeção numa nação do continente, uma etapa do desenvolvimento espiritual de um povo podem ser melhor e mais facilmente conhecidos através do cinema. Poderíamos citar vários exemplos, como essa admirável "Juarez", sobre um grande homem do México; "A casa dos corvos", que focaliza um trecho da história da Argentina; "A marquesa de Santos", que se refere a uma parte da história do Brasil, sem contar as películas descritivas de um país. Todas estas são obras que aproximam os povos do continente e fazem com que se conheça seu espírito, sua cultura e sua história. No mundo futuro, para a defesa dos princípios de liberdade e democracia, para o triunfo dos ideais de justiça social e econômica, o cinema será uma das ferramentas mais poderosas de estreitamento entre as nações latino-americanas. ${ }^{43}$

O cinema e o rádio já tinham sido percebidos como veículos de instrução que poderiam ser eficazes para uma política de massas que se inaugurava no período ${ }^{44}$. Através deles, a difusão cultural e a propaganda

41 LIMA, Melo. Palestra com Maria Rosa. Leitura, nov. 1943. p. 15.

42 Leitura, abr. 1943.

43 Leitura, 1943, p. 12-13.

44 Sobre este assunto, bem como sobre o debate do período entre esta concepção em contraposição àqueles que defendiam o rádio e o cinema como entretenimento e veí- 
política adquirem um caráter inseparável pois, além de controlar a difusão, o DIP produzia diversos programas e filmes como, por exemplo, o "cinejornal", de exibição obrigatória nos cinemas desde 1932. Eram curtas, chamados na época de shorts, sobre as atividades do governo. Os filmes históricos também eram apreciados por seu caráter educativo, justamente o tipo de filme mencionado pelo embaixador chileno ${ }^{45}$. Se para ele os filmes são capazes de "aproximar os povos dos continentes", em "Fronteira e cinema" ${ }^{46}$ Abelardo Montenegro observa o fenômeno de outra maneira. Falando sobre o cinema norte-americano, menciona a sua capacidade de "dilatar" as fronteiras. Doutrinário, "mesmo sem querer doutrinar", mostra a luta pela conquista da terra, a incorporação econômica e política de cidades longínquas de seu próprio território. Um dos objetivos, aliás, do governo Vargas para o Brasil: "a marcha para o oeste", estimulando o povoamento de imensas áreas ainda vazias $^{47}$. $\mathrm{O}$ movimento foi comparado ao dos bandeirantes e ao empreendido pelos norte-americanos, a que podíamos todos assistir nos filmes de farwest. O articulista faz a relação, e diz também que, se "tivéssemos cinema", poderíamos celebrar os feitos do colonizador, do bandeirante, do tropeiro, do vaqueiro, do negro, do caixeiro-viajante, do garimpeiro, etc... Ou seja, o cinema nos permitiria conhecer o povo e a cultura de cada recanto do país, bem como sua constituição. Função esta que já era exercida pelo rádio, pois,

Além de divulgar as mensagens e os atos oficiais, os diferentes pro gramas deveriam decantar as belezas naturais do país, descrever as características pitorescas das regiões e cidades, irradiar cultura, enaltecer as conquistas do homem em todas as atividades, incentivar relações comerciais. Muito se insistia no fato de que o rádio deveria

culo de mercadorias capazes de gerar lucros, ver Multidões em cena. Propaganda política no varguismo e no peronismo, de Maria Helena Capelato (São Paulo/Campinas: Fapesp/Papirus, 1998).

45 Convém ressaltar que $A$ marquesa de Santos é um filme argentino sobre a história do Brasil, adaptação do romance histórico homônimo de Paulo Setubal, originariamente intitulado Embrujo. Sua concepção já fazia parte, portanto, da própria política de boa vizinhança. Sobre a peculiaridade dessa produção argentina, há um artigo meu na revista daquele país, Grumo, editada em novembro de 2005 (RIO DOCE, Cláudia. A proliferação textual de Embrujo. Grumo, v. 4, 2005. p. 146-153.) Uma análise mais pormenorizada do filme foi empreendida no terceiro capítulo de minha tese de doutorado Roteiros. Roteiros. Roteiros. Roteiros. Roteiros. Roteiros. Cinema e modernismo.

46 MONTENEGRO, Abelardo. Fronteira e cinema. Leitura, maio 1943. p. 29.

47 Levine, ao comentar esta meta de Vargas de colonizar as fronteiras, menciona que ele foi o primeiro chefe de Estado a visitar os pontos mais distantes do país. Ver LEVINE, Robert M. op. cit. p. 101, 102. 
estar voltado para o homem do interior com o objetivo de colaborar para seu desenvolvimento e sua integração na coletividade nacional. ${ }^{48}$

A capacidade de dilatação da fronteira verificada pelo rádio e pelo cinema, então, pode ser entendida dupla e antagonicamente: num âmbito nacional, como unificadora, uma vez que pode servir como instrumento de inclusão social e, num âmbito internacional, como disseminadora, porque, além de afirmar uma unidade nacional, divulga e até exerce influências em outros países.

A questão da inclusão social, presente na ideia de unificação nacional, percorre também a preocupação, já apontada, de compromisso da arte com a realidade brasileira. Preocupação comum do Estado autoritário e dos militantes de esquerda, que através de um discurso populista torna-se capaz de aproximar inimigos e ideias contraditórias, transforma-se em clichê, gera produtos pasteurizados. O que é heterogêneo, por ser tratado superficial e apaziguadoramente, transforma-se em homogêneo. E desta forma temos, pelas páginas de Leitura, não só a crítica de Jorge de Lima aos seus colegas que abdicam de ideias próprias para realizar "coisas impessoais e informes", como o ataque à política de boa vizinhança por Silvio Julio ${ }^{49}$, que o qualifica de superficial, anárquico e ineficaz, na medida em que ignora as particularidades dos diferentes países da América Latina. Enfatiza, ainda, que o programa atende apenas aos interesses imperialistas. Jorge de Lima e Silvio Julio são vozes abafadas pela abundante propaganda contrária presente na própria revista.

A partir da leitura da revista, verificamos que a busca por um lugar onde as diferenças são harmonizadas é uma constante nas diversas questões abordadas: a aproximação entre o escritor e o público, a democratização da arte, as diversas adaptações entre línguas e linguagens (traduções, resumos de romances, adaptações cinematográficas), a inclusão social, a identificação com o outro (de forma que seja possível abordar uma questão política interna através do que acontece no exterior), apesar de haver, sempre, quem remarque este mesmo local como sendo de confronto e oposição. Podemos apreender também a ambiguidade deste lugar na concepção do conceito de fronteira, tal como aparece na revista, podendo ser interseção ou limite entre termos antagônicos ou complementares, o que nos permite aplicá-lo para pensar todas as diferentes questões encontradas em Leitura.

48 CAPELATO, Maria Helena R. op. cit. p. 77.

49 JULIO, Silvio. Programa de americanismo. Leitura, nov. 1943. p. 20. 